\title{
SEGMENTASI CITRA CT SCAN TUMOR OTAK MENGGUNAKAN MATEMATIKA MORFOLOGI (WATERSHED) DENGAN FLOOD MINIMUM OPTIMAL
}

\author{
Andi Hendra ${ }^{1}$ \\ 1Jurusan Matematika MIPA Universitas Tadulako
}

\begin{abstract}
ABSTRAK
Penelitian pengolahan citra digital dibidang medis yang memanfaatkan citra hasil CT scan telah banyak dilakukan. Salah satu penelitian yang telah dilakukan adalah identifikasi jenis tumor menggunakan citra dari hasil CT scan tumor otak. Sebelum proses identifikasi, dilakukan preprosessing pemisahan citra tumor dengan citra bukan tumor yang dikenal sebagai proses segmentasi. Watershed adalah salah metode segmentasi yang telah umum dikenal. Pada watershed, citra dipandang sebagai sebuah relief topografi dimana intensitas setiap piksel merepresentasikan ketinggian topografinya. Penelitian ini menggunakan watershed untuk melakukan proses segmentasi citra CT scan tumor otak dengan memperhitungkan nilai threshold untuk mendapatkan flood minimum yang optimal.
\end{abstract}

Kata kunci : citra ct scan, tumor, watershed, segmentasi, threshold, flood minimum

\section{Pendahuluan}

Mempermudah dan mempercepat proses pengolahan gambar.Segmentasi adalah proses pemisahan objek yang satu dengan objek yang yang lain dalam suatu gambar (citra) menjadi objekobjek berdasarkan karakteristik tertentu. Secara umum, proses segmentasi dikenal sebagai full segmentation dan partial segmentation. Full segmentation adalah pemisahan suatu object secara individu dari background dan diberi ID (label) pada tiap-tiap segmen. Sedangkan Partial segmentation adalah pemisahan sejumlah data dari background dimana data yang disimpan hanya data yang dipisahkan saja untuk mempercepat proses selanjutnya [1].

Watershed sebagai bagian dari matematika morfologi merupakan algorithma segmentasi citra yang telah dikenal cukup baik [2]. Hasil segmentasi dengan menggunakan watershed akan memberikan kurva tertutup dengan ketebalan satu piksel. Pada watershed, segmentasi dilakukan dengan mengasumsikan gambar sebagai suatu relief topolgi dimana intensitas setiap pixel mempresentasikan ketinggian topografinya [3]. Dalam sebuah permukaan topografi, apabila air hujan jatuh diatasnya, sesuai dengan hukum gravitasi maka air tersebut akan mengalir melewati jalur yang lebih rendah sampai ia mencapai ketinggian yang paling rendah atau minimum dimana ia tidak dapat mengalir kemana-mana lagi. Himpunan titik-titik pada permukaan topografi citra dimana aliran air yang melewatinya menuju ke minimum tertentu yang sama, menjadi sebuah catchment basin (cekungan yang terisi air) yang berasosiasi dengan minimum tersebut dan membentuk sebuah region citra. Namun, terkadang jumlah catchment basin yang terbentuk terlalu banyak atau bahkan terlalu sedikit karena proses flooding yang kurang optimal. Hal ini berakibat citra hasil segementasi yang diperoleh tidak merepresentasikan citra sebagaimana yang diinginkan. 
Pada penelitian ini, akan dilakukan segmentasi pada citra CT scan tumor otak menggunakan metode watershed dengan mencari threshold terbaiknya untuk mendapatkan flood minimum yang optimal.

\section{Watershed}

Konsep watershed sebagai sebuah metode untuk melakukan segmentasi terhadap citra diperkenalkan oleh C.Lantuejoul dan Sergei Beucher (1979) dan dikembangkan oleh Jean Serra (1982). Transformasi watershed memandang citra sebagai sebuah relief topografi dimana intensitas setiap pixel mempresentasikan ketinggian topografinya [3]. Dalam sebuah permukaan topografi, apabila air hujan jatuh diatasnya, sesuai dengan hukum gravitasi maka air tersebut akan mengalir melewati jalur yang lebih rendah sampai ia mencapai ketinggian yang paling rendah atau minima dimana ia tidak dapat mengalir kemana-mana lagi. Himpunan titik-titik pada permukaan topografi citra dimana aliran air yang melewatinya menuju ke minima tertentu yang sama, menjadi sebuah catchment basin (cekungan yang terisi air) yang berasosiasi dengan minima tersebut dan membentuk sebuah region citra [1].

Watershed terbentuk dilokasi dimana air dari kedua catchment basin yang berdekatan bertemu dan merupakan batas dari dua buah catchment basin tersebut. Keseluruhan watershed yang terbentuk menghasilkan seluruh kontur tertutup yang ada pada citra dan mempresentasikan obyek-obyek dalam citra yang telah tersegmentas. Gambar 1. menunjukkan ilustrasi algoritma watershed dalam satu dimensi. permukaan air pada Gambar 1 (a) akan terus bertambah. Untuk memisahkan dua catchment basins yang berbeda setelah permukaan air terus bertambah, dibentuk dam antara dua garis sebagaimana Gambar 1 (b).

Tujuan utama dari algoritma segmentasi berdasarkan konsep ini adalah mencari garis watershed (Beusher S). Ide dasarnya sangat sederhana: andaikan sebuah lubang dilubangi di setiap bagian minimumnya dan seluruh topografi memenuhi dari bawah dengan membiarkan air sampai ke lubang pada tingkat yang seragam. Ketika air yang naik di kolam penangkapan maka air akan bergabung, oleh karena itu sebuah bendungan (dam) dibangun untuk mencegah penggabungan. Banjir akhirnya mencapai tahap di mana hanya bagian atas bendungan yang bisa dilihat di atas garis air. Batas bendungan ini berhubungan dengan pembagian garis dalam watershed.

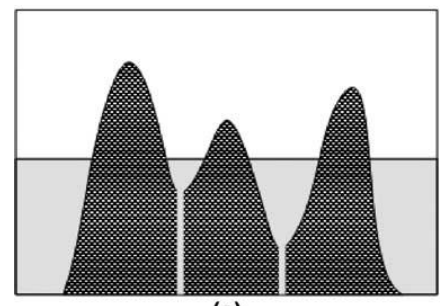

(a)

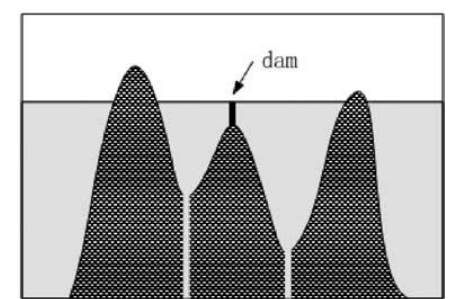

(b)

Gambar 1. Watershed pada Satu Dimensi. (a) Dam Belum Terbentuk pada Waktu t, (b) Dam Terbentuk pada Waktu $\mathrm{t}+\mathrm{b}$. 
Salah satu aplikasi dasar dari segmentasi watershed adalah ekstraksi dari seragam objek yang dekat dari background. Bagian citra yang mempunyai sifat variasi kecil di tingkat keabuan mempunyai nilai gradien yang kecil. Akan tetapi, pada kenyataannya kita sering melihat segmentasi watershed diaplikasikan ke gradien dari sebuah citra dari pada citra itu sendiri. Pada perumusan ini, regional minima dari kolam penangkapan berhubungan dengan nilai kecil dari gradien yang berhubungan ke objek yang diamati.

Contoh dapat dilihat pada Gambar 2 pada bagian (a) adalah citra asli. Pada bagian (b) adalah citra topografi. Citra topografi adalah bentuk citra 3 dimensi jika dilihat dari atas. Pada bagian(c)-(g) adalah tahap flooding. Pada bagian (h) dan (i) tampak dibangun dam agar dua buah catchment basin tidak bergabung. Bagian (j) adalah hasil akhir garis watershed.

Ada dua metode utama yang terdapat dalam transformasi watershed terhadap citra yang merupakan representasi ulang dari simulasi watershed dalam konsep topografi. Kedua metode tersebut mengacu pada konsep flooding dalam yang menggambarkan perilaku air dalam suatu relief topografi. Metode pertama disebut sebagai watershed dengan simulasi perendaman (immersion simulation), dan metode kedua adalah dengan simulasi air hujan (rainfall simulation).

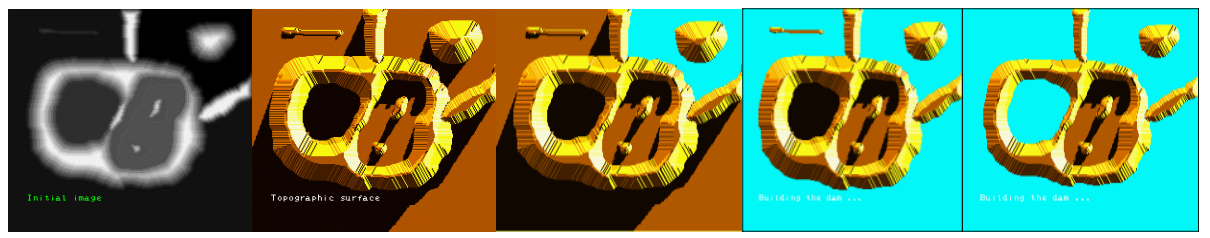

(a)

(b)

(c)

(d)

(e)

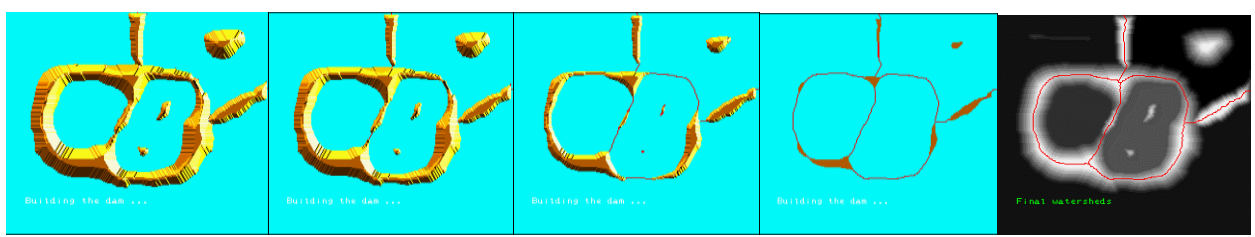

(f)

(g)

(h)

(i)

(j)

Gambar 2. Pembentukan Watershed (a) Citra asli. (b) Pemandangan topografik. (c)-(g) Lima Tahap Flooding (h) Awal Penggabungan Dua Kolam.(i) Pembentukan Dam. (j) Garis Watershed pada Citra

\section{II.1. Proses Watershed}

Setelah citra sample diperoleh, dilakukan proses untuk mencari garis watershed yg merepresentasikan objek yang akan di segmentasi. Proses mencari garis watershed sebagaimana ditunjukkan pada Gambar 3. Proses di awali dengan mencari banyaknya jumlah catchment basin pada setiap flood minimal. Pada proses ini, juga dicari gradient perbedaan jumlah catchment basin pada setiap flood minimal untuk mencari watershed dengan gradient jumlah catchmen basin terbesar. selanjutnya dicari selisih jumlah catchment basin pada setiap flood minimal pertama dengan flood minimal tertentu. Dari hasil pencarian selisih ini, dapat dicari flood minimal yang baru 
dengan nilai treshold tertentu. Hasil pencarian flood minimal yang baru inilah yang dijadikan masukan (input) untuk melakukan penggabungan catchment basin untuk mendapatkan citra watershed dengan garis watershed terbaik.

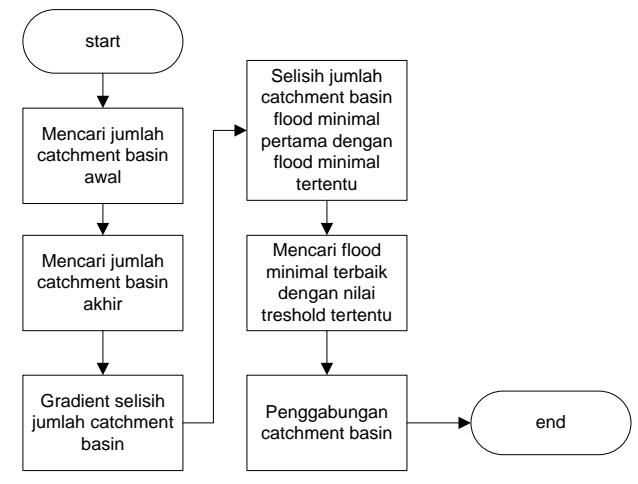

Gambar 3. Proses watershed

\section{II.1.1. Jumlah Catchment Basin}

Pada proses ini, dicari banyaknya jumlah catchment basin pada setiap flood minimal. Pertama- tama adalah dihitung banyaknya jumlah catchment basin awal pada setiap flood minimal. Proses ini diawali dengan mencari gradient magnitude dari image. Jumlah catchment basin awal dihitung dari maksimal jumlah kolam yang diperoleh dari hasil watershed dengan citra masukan berupa gradient magnitude. jumlah catchment basin pada tahap ini akan sangat banyak dikarenakan ukuran dari catchment basin yang sangat kecil. Citra watershed yang diperoleh sampai pada tahap ini belum dapat merepresentasikan objek yang dimaksud. Olehnya itu diperlukan proses yang lebih lanjut. Setiap catchment basin yang telah diperoleh, diberikan label. Dengan proses pelabelan ini maka tetangga dari setiap catchment basin (label) dapat diketahui. Untuk setiap label image $G=[R, E]$, yang merepresentasikan catchment basin yang saling bertetangga, di asumsikan bahwa setiap tepi $e_{i j} \in E$ dan $r_{i} \in R$, dimana $E$ adalah tepi (edge) dari catchment basin satu dengan yang lain, dan $\mathrm{R}$ adalah catchment basin [4].

Untuk mendapatkan informasi bahwa suatu catchment basin bertetangga dengan catchment basin yang lain, digunakan 8 connected component. Matriks dari 8 connected component dijalankan mulai dari ujung kiri atas hingga ujung kanan bawah image. Selanjutnya dicari label dari catchment basin yang merepresentasikan garis watershed dari image. Empat kemungkinan yang digunakan untuk mengecek apakah dua catchment basin adalah tetangga atau bukan adalah dengan membandingkan antara tetangga sebelah atas dengan bawah, atas kanan dangan bawah kiri, sebelah kanan dengan kiri, dan sebelah kanan bawah dengan atas kiri. Dari empat kemungkinan ini, di lakukan pengecekan pada masing- masing label catchment basin untuk memastikan ketetanggaan dari catchment basin. Jika tidak memenuhi salah satu dari keempat kemungkinan yang ada, berarti terdapat hanya satu catchment basin dan tidak dapat digabungkan. Kedua label 
tersebut selanjutnya disimpan dalam graph $G$ dimana baris matriks dengan label pertama dan kolom matriks dengan label kedua ditambahkan satu. Selanjutnya adalah mencari gradient terendah (bobot) pada titik common boundary dua catchment basin yang saling bertetangga.

Setelah didapatkan informasi banyaknya catchment basin pada setiap flood minimal, dilakukan analisis untuk melihat perubahan jumlah catchment basin pada setiap flood minimalnya. Persamaan ini dapat dihitung dengan mencari selisih antara jumlah catchment basin akhir pada flood minimal tertentu dengan jumlah catchment basin akhir pada flood minimal sebelumnya. Sehingga akan nampak perbedaan jumlah catchment basin pada kondisi tertentu dengan kondisi sebelum atau sesudahnya. Flood minimal yang akan digunakan adalah flood minimal dari nilai gradient yang terpilih ditambahkan satu. Hal ini sesuai dengan persamaan gradient berikut

$$
\operatorname{grad}=\left|N_{i+1}-N_{i}\right| \text {, }
$$

dimana, $i=2,3, \ldots, n$. Grad menyatakan banyaknya selisih antara jumlah catchment basin pada flood minimal $i+1$ dan $i$. $N_{i+1}$ adalah jumlah catchment basin pada flood minimal $i+1$.

\section{II.1.2. Selisih Jumlah Catchment Basin}

Langkah selanjutnya adalah melakukan perhitungan selisih antara jumlah catchment basin pada setiap flood minimal dengan jumlah catchmen basin sebelum dilakukan penggabungan. Hal ini dimaksudkan untuk melihat pola dari grafik perubahan jumlah catchmen basin. Hasil dari perhitungan ini akan memberi gambaran dan informasi yang akan digunakan untuk menentukan batas treshold untuk menentukan flood minimal terbaik yang akan digunakan pada proses selanjutnya [4]. Persamaan untuk mendapatkan selisih tersebut diberikan pada rumus berikut

selisih $=\left|N_{1}-N_{i}\right|$,

dimana, $i=2,3, \ldots, n$.

Selisih menyatakan banyaknya selisih antara jumlah catchment basin pada flood minimal 1 dan $i$ . $N_{i}$ adalah jumlah catchment basin pada flood minimal $i$.

\section{II.1.3. Penggabungan Catchment Basin}

Hasil perhitungan selisih jumlah catchment basin akan memberikan informasi sehingga nilai batas threshold flood minimal terbaik dapat ditentukan. Nilai batas threshold yang dimaksudkan disini adalah persentasi dari keseluruhan nilai selisih jumlah catchmen basin tertinggi. Nilai flood minimal terbaik dengan batas threshold yang telah ditentukan inilah yang akan diproses pada algoritma penggabungan watershed. Hasil penggabungan catchmen basin dengan flood minimal terbaik akan memberikan citra watershed dengan garis watershed yang dapat merepresentasikan objek yang dimaksud [4].

\section{Implementasi}

Tulisan ini diimplementasikan dengan menggunakan perangkat lunak MATLAB (R2008b) dengan menggunakan empat citra CT Scan tumor otak yang berbeda. Gambar dibawah menunjukkan hasil segmentasi citra CT scan tumor otak dengan pemilihan threshold terbaik 

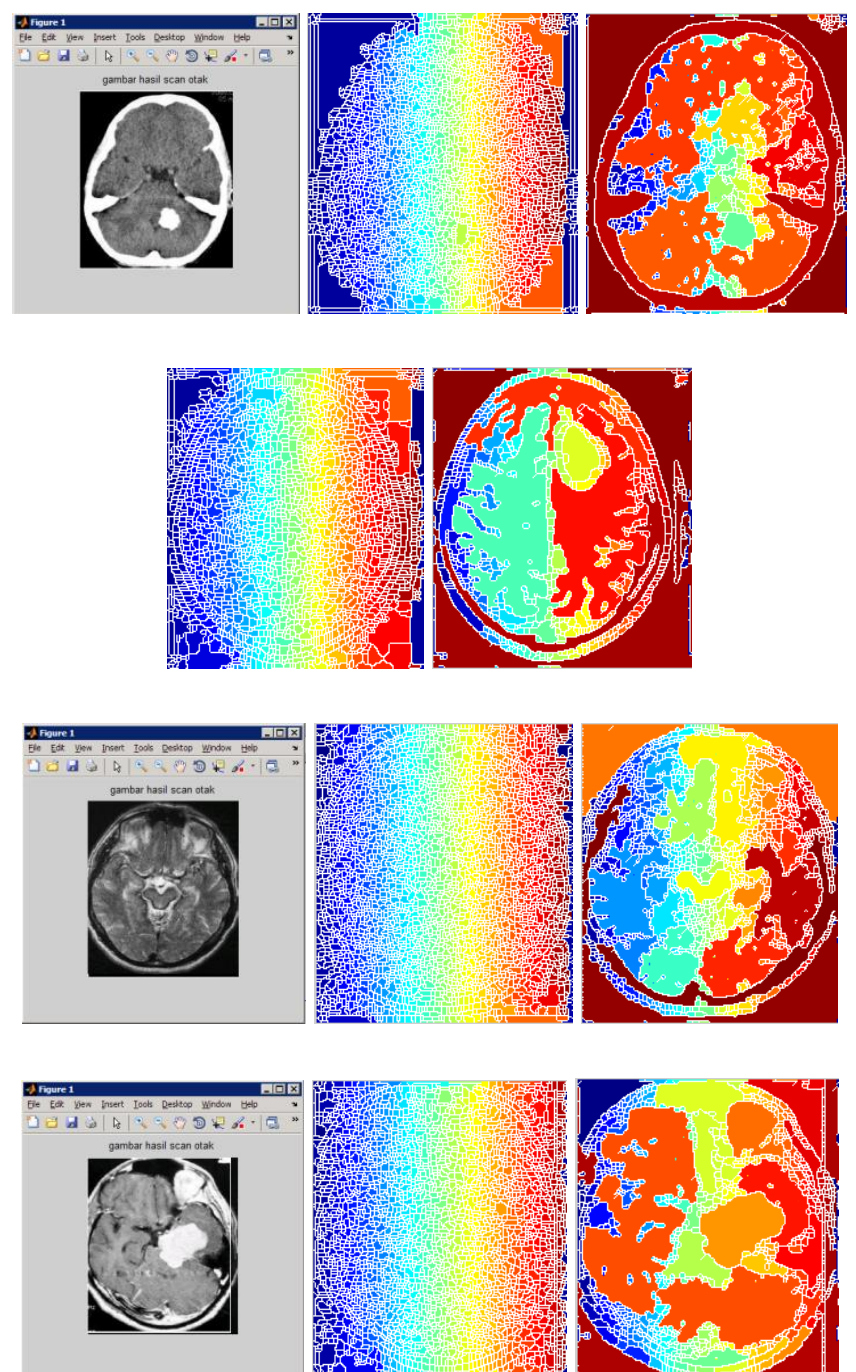

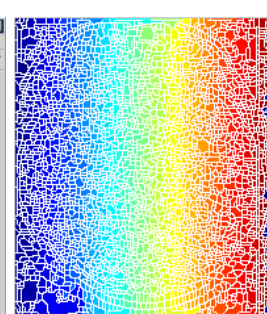

(b)

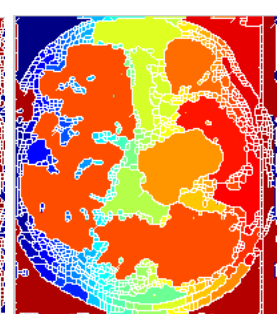

(c)

Gambar 4. Segmentasi pada pada citra CT scan tumor otak (a) citra asli, (b) hasil segmentasi dengan catchment basins awal, (c) hasil segmentasi dengan catchment basins akhir (dengan flood minimum optimal)

\section{Hasil dan Pembahasan}

Hasil perhitungan catchment basins, nilai threshold serta flood minimum optimal, selengkapnya diberikan pada table 1 berikut serta gambar 4 di atas. 
Table 1. perhitungan catchment basins, threshold, dan flood min optimal

\begin{tabular}{|c|c|c|c|c|}
\hline Citra uji & $\begin{array}{c}\text { Catchment } \\
\text { basins awal }\end{array}$ & $\begin{array}{c}\text { Catchment } \\
\text { basins awal }\end{array}$ & $\begin{array}{c}\text { Threshold } \\
(\%)\end{array}$ & $\begin{array}{c}\text { Flood min } \\
\text { optimal }\end{array}$ \\
\hline CT Scan tumor otak-1 & 3260 & 508 & 0.99 & 48 \\
\hline CT Scan tumor otak-2 & 2391 & 617 & 0.98 & 46 \\
\hline CT Scan tumor otak-3 & 3612 & 1131 & 0.98 & 49 \\
\hline CT Scan tumor otak-4 & 3251 & 880 & 0.98 & 47 \\
\hline
\end{tabular}

Ke empat citra uji memiliki selisih jumlah catchment basins awal yang cukup besar. Hal ini berarti bahwa citra hasil segmentasi awal yang diperoleh belum dapat merepresentasikan objek yang dimaksud. Karena terlalu banyaknya catchment basins hingga mengaburkan objek yang sebenarnya, dilakukan penggabungan pada setiap tahapan flood minimum dengan mencari nilai threshold terbaiknya hingga diperoleh flood minimum yang paling optimal.

\section{Kesimpulan}

Berdasarkan hasil yang diperoleh, dapat ditarik kesimpulan bahwa :

a. Flood minimum yang optimal pada metode watershed dapat diperoleh dengan mencari nilai thresholdnya.

b. Adanya preprosessing reduksi noise, memungkinkan diperoleh hasil segmentasi citra yang lebih baik.

\section{Daftar Pustaka}

1) Adipranata Rudy, Andreas Handojo, Ivan Prayogo, Oviliani Yenty Yuliana, perancangan dan pembuatan aplikasi Segmentasi gambar dengan menggunakan Metode morphological watershed, Jurursan Teknik Informatika-Universitas Petra, (2005)

2) Chen Guang Zhao, Tian Ge Zhuang, "A Hybrid Boundary Detection Algorithm Based on Watershed and Snake" Elsevier, Pattern Recognition Letters 26 (2005) 1256-1265.

3) Gonzalez, R.C., Woods, R.E. Digital Image Processing Second Edition, Prentice Hall, New Jersey. (2002)

4) R. Lotufo, w. Silva, minimal set of markers for the watershed transform, faculty of electrical and computer engineering Universidade estadual de campinas, campinas-sp, brazil., 2002 